\title{
The history of the Scania engines
}

\begin{abstract}
Scania is one of the leading manufacturers of heavy-duty trucks worldwide. The engines designed for these vehicles constitute an important sector of this company's product range. Scania treats the development of their engines with particular care. High expenditure on research and development as well as long established tradition make this product unique in many ways. These engines comprise experience, durability and novelty and that is why the Scania engines conform to the most stringent standards and market requirements. The paper presents a concise history of the development of the truck engines that are only a part of the company's production beside industrial and marine engines. The history of the Scania engines shows how a combustion engine developed throughout decades, particularly diesel engines. This paper also proves that such a development is not only still possible but also quick, bringing measurable results.
\end{abstract}

Key words: combustion engines, engines development, heavy-duty tracks

\section{Rozwój silników pojazdów ciężarowych Scania}

\begin{abstract}
Scania jest jedna z wiodacych firm na świecie produkujących pojazdy ciężarowe. Silniki przeznaczone dla tych pojazdów stanowia wyjątkowo ważna gałaź produkcji firmy. Scania w sposób szczególny traktuje rozwój silników, które dzięki bardzo dużym naktadom na badania oraz dlugiej tradycji sa wyjątkowe pod wieloma względami. Łacza w sobie doświadczenie, solidność wykonania i nowoczesność. Dzięki temu silniki Scania spetniają najwyższe standardy i wymagania rynku. Artykut przedstawia krótka historię rozwoju silników przeznaczonych do napędu pojazdów ciężarowych, które stanowia tylko cześć produkcji firmy obok silników przemysłowych oraz silników morskich. Historia silników Scania pokazuje jak rozwijat się silnik spalinowy, a w szczególności silnik z zapłonem samoczynnym, w ciagu wielu lat jej historii. Jednocześnie dowodzi, że rozwój ten nie tylko jest wciąż możliwy, ale przebiega w sposób bardzo szybki i przynosi wspaniate efekty.
\end{abstract}

Słowa kluczowe: silnik spalinowy, rozwój silników, pojazdy ciężarowe

\section{Introduction}

A combustion engine is the most important subassembly of a heavy-duty truck. Its performance, durability, reliability and environmental impact are decisive of its success. A truck engine is a bit like a human's heart that has to be strong, reliable and clean. Many factors influence the design of such an engine. One of the most important are: expertise and knowledge of the design engineers, research and design potential of the manufacturer, type and quality of the applied building materials, technology of production, legal requirements or client expectations. It is the clients that give the final verdict on the engine based on their experiences and engine maintenance costs.

\section{The beginnings}

It was 1916 when the first V8 engine (spark ignition) was manufactured in Scania-Vabis still distinguishing Scania among other truck manufacturers. Since 1919 the company has been manufacturing heavy-duty trucks exclusively. At that time the first attempts to optimize the production process were made consisting in using the same subcomponents for 1.5-, 2.5- and 3-ton vehicles. Trucks built in a modular system were simple and affordable (production and operation). August Nilsson - head of the plant in Södertälje and one of the plant's engineers Tage Söderberg preached and practiced a principle that the simplest solution is an ingenious solution". In 1926 Scania launched a multi fuel

\section{Wstęp}

Silnik spalinowy jest najważniejszym zespołem pojazdu ciężarowego. Osiągi, trwałość, niezawodność oraz wpływ na środowisko naturalne decydują o jego ocenie. $Z$ silnikiem ciężarówki jest trochę tak jak z sercem, które musi być mocne, niezawodne i czyste. Na jego konstrukcję ma wpływ bardzo wiele czynników. Do najważniejszych z nich należą: doświadczenie i wiedza konstruktorów, potencjał projektowy i badawczy firmy, rodzaj i jakość zastosowanych materiałów konstrukcyjnych, technologia produkcji, wymogi prawne, oczekiwania klientów. To oni w ostatecznie wydają opinię o silniku na podstawie swoich doświadczeń i kosztów eksploatacji pojazdu.

\section{Początki rozwoju}

W roku 1916 w firmie Scania-Vabis powstał pierwszy silnik V8 (z zapłonem iskrowym), którego symbol aż do dzisiaj wyróżnia Scanię wśród producentów pojazdów ciężarowych. Od roku 1919 firma skoncentrowała się wyłącznie na produkcji pojazdów ciężarowych. Wtedy rozpoczęto pierwsze próby optymalizacji procesu produkcji polegające na stosowaniu tych samych elementów do pojazdów 1,5-, 2,5- oraz 3-tonowych. Modułowo budowane ciężarówki były proste i tanie zarówno $\mathrm{w}$ produkcji, jak również $\mathrm{w}$ eksploatacji. August Nilsson - dyrektor fabryki w Södertälje oraz jeden z jej inżynierów Tage Söderberg wprowadzili w czyn zasadę: ,genialne rozwiązanie to rozwiązanie naj- 
ready engine (including ethanol) built according to the Jonas Hasselman's concept. In 1939 „Royal” was shown - the first unified diesel engine that paved the way to the modular engine manufacturing. These engines were called "unified". In 4-, 6- and 8-cylinder variants the same cylinder heads, pistons, piston rods, bearings and exhaust manifolds were used (Fig. 1).

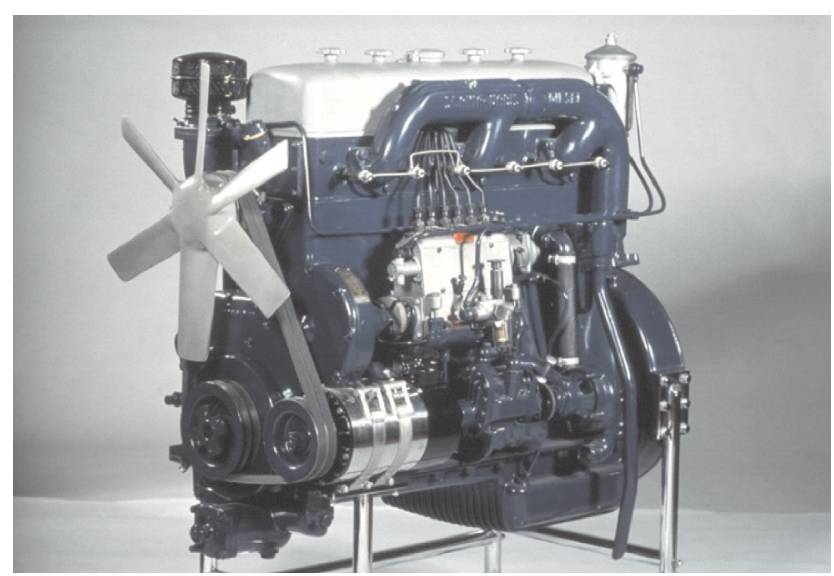

Fig. 1. The first diesel engine by Scania-Vabis 88 kW (120 BHP), year 1936

Rys. 1. Pierwszy silnik z zapłonem samoczynnym firmy Scania-Vabis o mocy $88 \mathrm{~kW}(120 \mathrm{KM})$, rok 1936

\section{Durability, reliability and high power}

After the war Scania reinforced their position in the market by offering engines that at that time were very durable and reliable. In 1949 a production began of $85 \mathrm{~kW}$ (115 BHP) and $99 \mathrm{~kW}$ (135 BHP) six cylinder direct injected diesel engines D610/620. Vehicles fitted with these engines reached a rebuild mileage of approximately $400,000 \mathrm{~km}$. The drivers that reached such a mileage were awarded with wrist watches and special placards to put on their vehicles. Yet, at the end of the 1950s of the 20th century this awarding stopped, as the mileage for which the drivers were awarded became a common thing (Fig. 2).

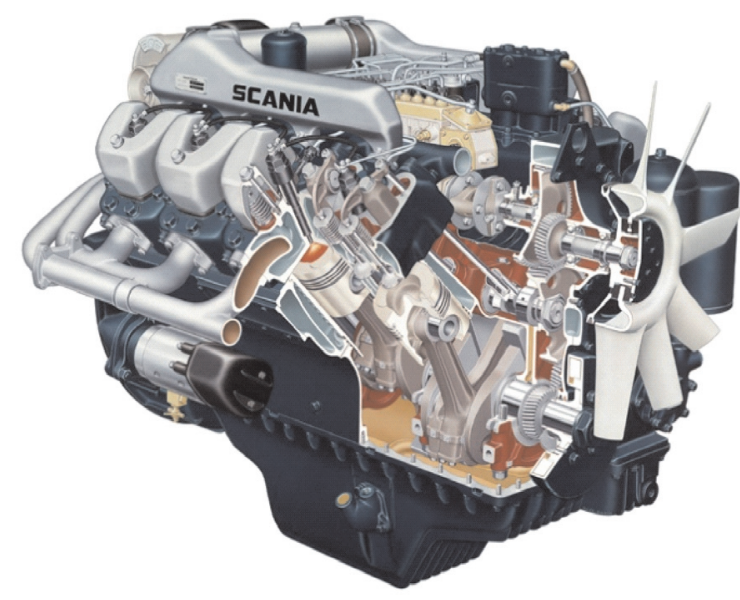

Fig. 3. Scania engine DS14, V8 257 kW (350 BHP), year 1969 Rys. 3. Silnik Scania DS14, V8 257 kW (350 KM), rok 1969 prostsze". W roku 1926 Scania wprowadziła na rynek silnik wykonany według koncepcji Jonasa Hasselmana, przystosowany do zasilania różnymi paliwami, w tym etanolem. W roku 1939 zaprezentowany został „Royal” - pierwszy zunifikowany silnik z zapłonem samoczynnym, który dał początek systemowi modułowej produkcji silników. Silniki te nazwane były „silnikami zunifikowanymi”. W 4-, 6- i 8-cylindrowych wariantach występowały te same głowice, tłoki, korbowody, łożyska i kolektory wylotowe (rys. 1).

\section{Trwałość, niezawodność i duża moc}

Po wojnie Scania umocniła swoją pozycję na rynku, oferując, w odniesieniu do tamtych czasów, bardzo trwałe i niezawodne silniki. W roku 1949 rozpoczęto produkcję sześciocylindrowych silników D610/620 z zapłonem samoczynnym, z wtryskiem bezpośrednim o mocy $85 \mathrm{~kW}$ (115 KM) i 99 kW (135 KM). Pojazdy wyposażone w te silniki osiągały przebieg ok. $400000 \mathrm{~km}$ bez remontu głównego. Kierowcy, którzy osiągali taki przebieg otrzymywali od firmy zegarki i specjalne plakietki na pojazdy. Jednak pod koniec lat pięćdziesiątych XX w. zaprzestano ich rozdawania, ponieważ przebiegi, za które nagradzano kierowców dla pojazdów $\mathrm{z}$ silnikami Scania przestały być wyjątkowe (rys. 2).

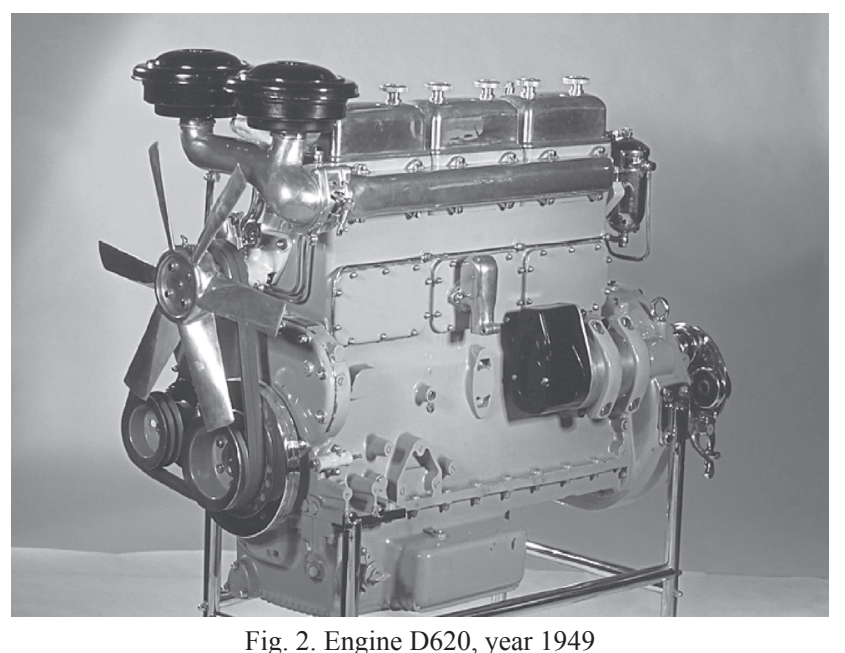

Rys. 2. Silnik D620, rok 1949

Do zbudowania legendy silnika V8 bardzo znacząco przyczynił się turbodoładowany silnik DS14 z 1969 r. W tym czasie był to najmocniejszy silnik stosowany $\mathrm{w}$ pojazdach ciężarowych. W latach 1969-1976 sprzedano 12160 pojazdów wyposażonych w tę jednostkę napędową. Silnik rozwijał moc $257 \mathrm{~kW}$ przy prędkości obrotowej $2300 \mathrm{1} / \mathrm{min}$ oraz osiągał moment obrotowy $1250 \mathrm{~N} \cdot \mathrm{m}$ przy prędkości obrotowej 1000-1400 1/min. Stopień sprężania wynosił 15, średnica tłoka $140 \mathrm{~mm}$, a średnica cylindra 127 mm. Paliwo podawane przez rzędową pompę wtryskową Boscha $\mathrm{z}$ regulatorem odśrodkowym wtryskiwane było pięciootworowymi wtryskiwaczami, których ciśnienie otwarcia wynosiło 203 bar. Silnik ten przyczynił się do nadania samochodom Scania popularnego określenia: „królowa szos” (rys. 3). 
To the design of the legendary V8 engine largely contributed the turbocharged DS14 from 1969. At that time this was the most powerful engine used in trucks. In the years 1969-1976 12160 vehicles fitted with this engine were sold. The engine had a power output of $257 \mathrm{~kW}$ at $2300 \mathrm{rpm}$ and a torque of $1250 \mathrm{~N} \cdot \mathrm{m}$ at $1000-1400 \mathrm{rpm}$. The compression ratio was 15 , piston bore $140 \mathrm{~mm}$, and cylinder bore 127 $\mathrm{mm}$. The fuel was fed through a Bosch in-line injection pump with a centrifugal regulator and injected through five hole injectors whose opening pressure was 203 bar. This engine contributed to the Scania's nickname "King of the Roads" (Fig. 3).

\section{A tailor-made engine}

In the 1980 s of the $20^{\text {th }}$ century the company introduced a notion: "a tailor-made truck". Tailored made trucks were all engines whose size and performance were adapted to the applications of a given vehicle and the expectations of the client for whom a selection of vehicles from 18 to 36 tons (second generation Scania) was prepared in the years 1980-81. In these vehicles 8 and $11 \mathrm{dm}^{3}$ engines were fitted of power outputs of $235 \mathrm{~kW}$ (320 BHP) and $265 \mathrm{~kW}(360$ BHP) as well as a 14-liter engine. 1982 saw a new intercooled version of this engine of power outputs of $309 \mathrm{~kW}$ (420 BHP) (at that time this was the most powerful engine used in heavy duty vehicles). Five years later this engine was the first to have EDC (electronic diesel control- fuel injection control), which increased its power to $346 \mathrm{~kW}$ (470 BHP). At the end of the 1980s together with the launch of the third generation Scania vehicles the company began production of $9 \mathrm{dm}^{3}$ engines of power outputs of $184 \mathrm{~kW}$ (250 BHP) and $206 \mathrm{~kW}$ (280 BHP).

\section{Scania turbocompound}

With a view to boost the engine efficiency in 1991 a solution was implemented going by the name of "turbocompoud" aiming at recuperating as much energy contained in the exhaust as possible and converting it into work. To this end in a 11 liter DTC11 01 engine, a system with an additional turbine was fitted, the power from which was directly transferred to the engine crankshaft. An additional drive of the crankshaft was realized through a gearset reducing the turbine speed from $50000 \mathrm{rpm}$ to the speed of the crankshaft as well as the hydraulic clutch fitted between these two. The DTC11 01 engine had a power output of $294 \mathrm{~kW}$ (400 BHP) at $1900 \mathrm{rpm}$ and the torque of $1750 \mathrm{~N} \cdot \mathrm{m}$ at $1200-1500 \mathrm{rpm}$ (Fig. 4).

\section{Technological advancement with respect to the environment protection and client expectations}

In the fourth generation of their vehicles in 1996 Scania launched engines complying with the Euro 2 emission standard. The fuel injection was done through an in-line injection pump. In the popular 12-liter model DSC12 01 of the power output of $294 \mathrm{~kW}$ (400 BHP) an EDC engine control unit was used. The engines had divided cylinder heads that facilitated the engine maintenance, and four valves per cylinder responsible for the charge exchange. A closed

\section{Silnik dla pojazdów „na miarę”}

W latach osiemdziesiątych XX w. w firmie wprowadzono określenie: „samochód ciężarowy na miarę”. „Na miarę" musiały być również silniki, których wielkości i osiągi dostosowano do potrzeb wynikających z zastosowania pojazdu i wymagań użytkownika, dla którego w latach 1980-81 przygotowano gamę pojazdów o masie całkowitej od 18 do 36 ton (Scania drugiej serii). W samochodach tych zastosowanie znalazły silniki o pojemności $8 \mathrm{dm}^{3}$, popularne silniki 11-litrowe o mocach $235 \mathrm{~kW}(320 \mathrm{KM})$ i $265 \mathrm{~kW}(360 \mathrm{KM})$ oraz silnik czternastolitrowy. W roku 1982 na rynku pojawiła się nowa jego odmiana o mocy 309 $\mathrm{kW}(420 \mathrm{KM}) \mathrm{z}$ intercoolerem ( $w$ tym czasie najmocniejszy silnik stosowany w pojazdach ciężarowych), który pięć lat później jako pierwszy otrzymał układ EDC (electronic diesel control) do sterowania wtryskiem paliwa, co pozwoliło na podniesienie jego mocy do $346 \mathrm{~kW}$ ( $470 \mathrm{KM}$ ). Pod koniec lat osiemdziesiątych minionego wieku wraz z wprowadzeniem na rynek trzeciej serii pojazdów Scania zaczęła produkować silniki dziewięciolitrowe o mocach 184 kW (250 KM) i 206 $\mathrm{kW}(280 \mathrm{KM})$.

\section{Scania turbocompound}

Z myślą o podniesieniu sprawności ogólnej silnika w 1991 r. wprowadzono rozwiązanie o nazwie „turbocompoud", które miało na celu odzyskanie jak największej energii zawartej w spalinach i zamianę jej na pracę użyteczną. $\mathrm{W}$ tym celu w jedenastolitrowym silniku DTC11 01 zastosowano układ z dodatkową drugą turbiną, z której moc przekazywana była na wał korbowy silnika. Dodatkowy napęd wału korbowego silnika umożliwiał zespół kół zębatych, powodujący redukcję prędkości wałka turbiny z 50000 obr/min do prędkości obrotowej wału korbowego, i sprzęgło hydrauliczne zamontowane pomiędzy dodatkową turbiną i wałem korbowym silnika. Silnik DTC11 01 osiaggał moc 294 kW (400 KM) przy prędkości obrotowej 1900 1/min oraz moment obrotowy $1750 \mathrm{~N} \cdot \mathrm{m}$ przy prędkości obrotowej silnika 1200-1500 1/min (rys. 4).

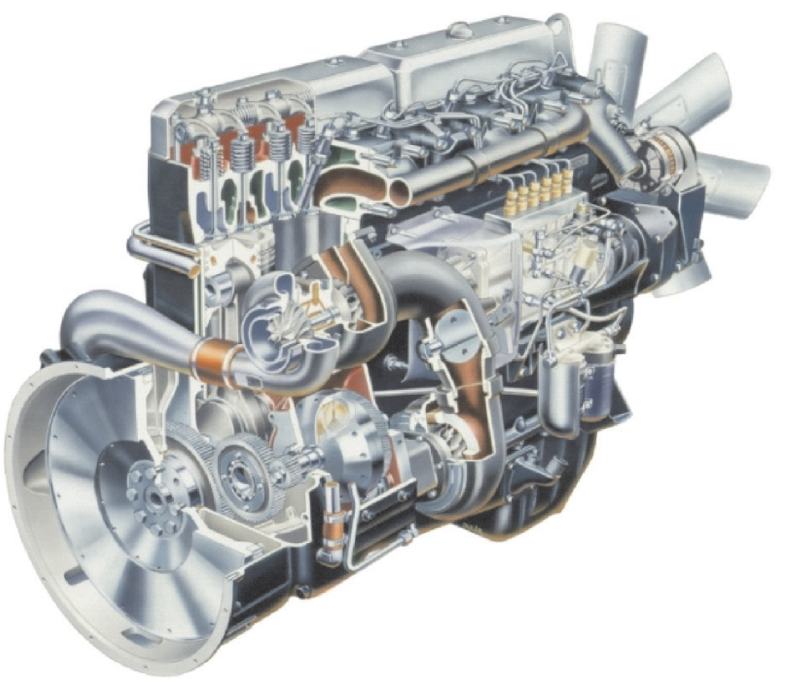

Fig. 4. DTC11 01 with the turbocompound system, year 1991 Rys. 4. Silnik DTC11 01z uktadem turbocompound, rok 1991 
crankcase blow-by system was used in this engine as well. In the engines complying with the Euro 3 emission standard fuel supply systems using pump nozzles (PDE) by Bosch were used (Fig. 5 and 6).

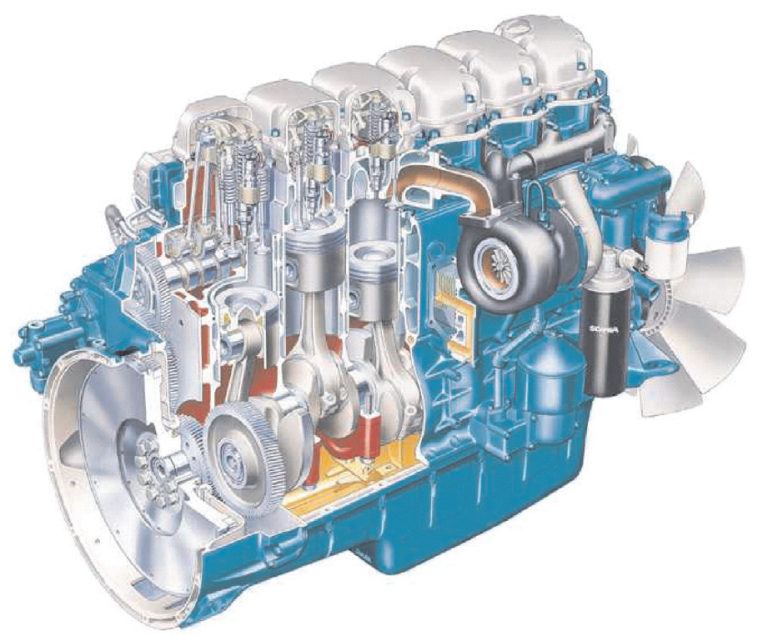

Fig. 5. Scania DSC11 Euro 3 of power output of 279 kW (380 BHP), year 1999

Rys. 5. Silnik Scania DSC11 Euro3 o mocy 279 kW (380 KM), rok 1999

The "turbocompound" system introduced in the beginning of the 1990s of the 20th century was also applied in the family of the 12-liter engines (DT12) fitted with a high pressure fuel injection (HPI) complying with the Euro 3 emission standard (DT12 06 of power output of $346 \mathrm{~kW}$ (470 BHP) and Euro 4 (DT12 17 of power output of 353 kW (480 BHP). The history of the high-pressure fuel injection in the Scania engines began in 1992 with a joint project with Cummins. The systems that came to life as a result of this collaboration was ready in 1999 and was first used in the Cummins engines and after two years in the Scania HPI engines. The most critical element of the HPI system is the pump nozzle with a divided piston allowing such high pressures (Fig. 7).

The pump nozzle can change the parameters of the injection through an adjustment of the distance between two elements of the divided piston. This distance is changed through the amount of fuel between the divided elements. Additionally, using the temperature increase of the compressed fuel the system design enables a fuel preheat in the fuel tank (Fig. 8).

The HPI system has been fitted in the Euro 3, Euro 4 and Euro 5 engines since 2001. An example of a typical engine using HPI and complying with the Euro 4 emission standard is DT12 12 with the turbocompound and EGR systems while the DT12 $15 \mathrm{HPI}$ of power output of $309 \mathrm{~kW}$ (420 BHP) is additionally fitted with SCR (selective catalytic reduction) and complies with the Euro 5 emission standard (Fig. 9).

\section{New Scania engine family}

In 2007, two years before the Euro 5 emission standard became applicable, Scania presented a new engine family,

\section{Rozwój z myślą o ochronie środowiska i oczekiwaniach klienta}

Wraz z czwartą serią pojazdów w 1996 r. Scania wprowadziła silniki spełniające normy Euro 2. Wtrysk paliwa realizowano na pomocą rzędowej pompy wtryskowej. W popularnym dwunastolitrowym modelu DSC12 01 o mocy 294 kW (400 KM) zastosowano układ sterowania silnikiem EDC. Silniki miały dzielone głowice, ułatwiające obsługę, oraz cztery zawory sterujące wymianą ładunku w każdym z cylindrów. Pojawił się także zamknięty układ odpowietrzania skrzyni korbowej. W silnikach spełniających normy Euro 3 zastosowano układy zasilania z pompowtryskiwaczami typu PDE firmy Bosch (rys. 5 i 6).

Układ ,turbocompound”, wprowadzony na początku lat dziewięćdziesiątych XX w., znalazł zastosowanie również w rodzinie dwunastolitrowych silników DT12 z wysokociśnieniowym wtryskiem paliwa HPI (high pressure injection), spełniających standardy Euro 3 (silnik DT12 06 o mocy 346 kW (470 KM)) i Euro 4 (silnik DT12 17 o mocy 353 kW (480 KM)). Historia wysokociśnieniowego wtrysku paliwa w silnikach Scania rozpoczyna się w 1992 r. wspólnym projektem z firmą Cummins. Powstały w wyniku tej współpracy układ był gotowy w 1999 r. i zastosowano go najpierw w silnikach Cummins, a po dwóch latach w silnikach Scania HPI. Najważniejszym elementem układu HPI jest pompowtryskiwacz z dzielonym tłokiem umożliwiającym uzyskanie wysokiego ciśnienia wtrysku (rys. 7).

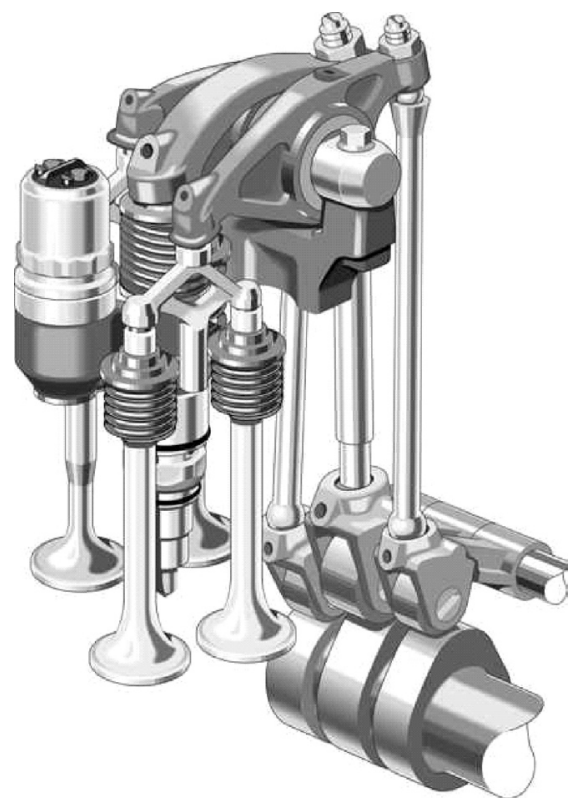

Fig. 6. Valve and pump nozzle drive in $\mathrm{DSC} 16 \mathrm{~V} 8$

Rys. 6. Napęd zaworów i pompowtryskiwacza silnika DSC16 V8

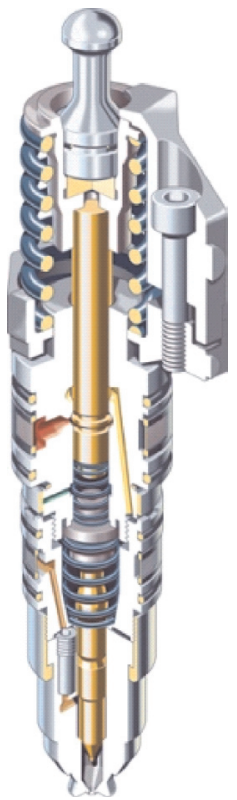

Fig. 7. HPI pump nozzle

Rys. 7. Pompowtryskiwacz HPI
Pompowtryskiwacz daje możliwość zmiany parametrów wtrysku paliwa przez regulację odległości pomiędzy dwoma elementami podzielonego tłoka. Odległość ta zmieniana jest przez zmianę ilości paliwa doprowadzanego pomiędzy elementy podzielonego tłoka. Dodatkowo, wykorzystując 


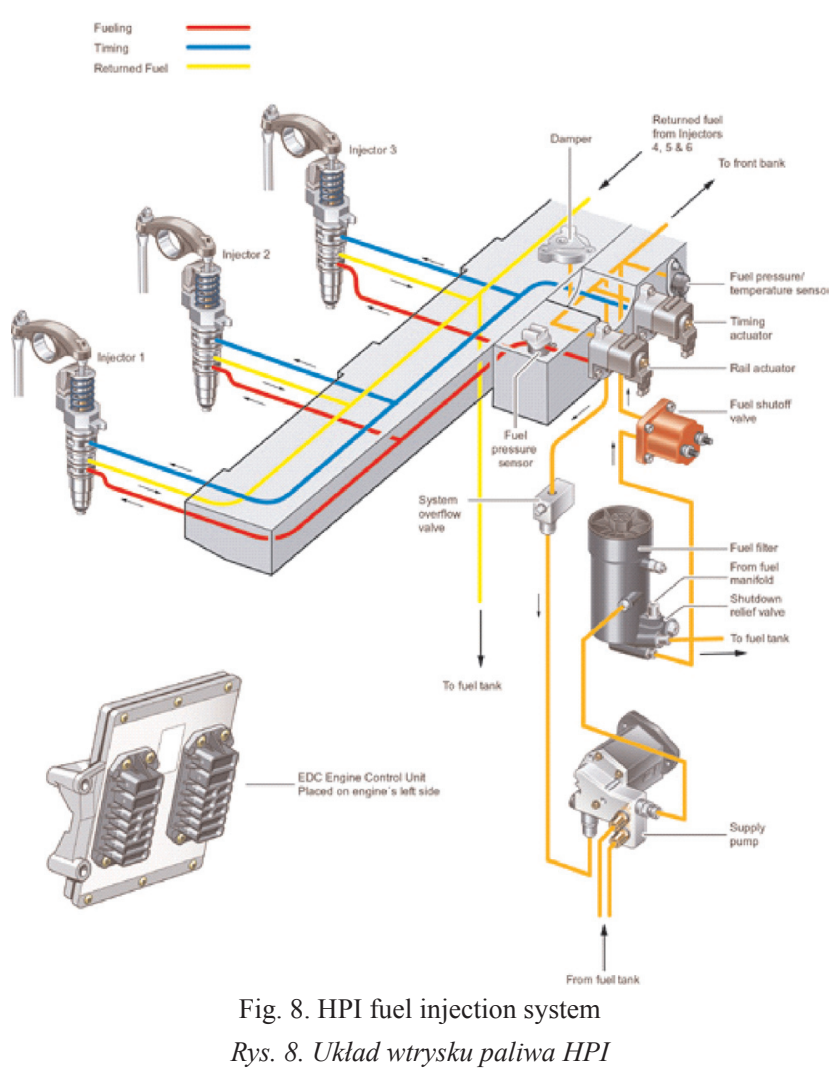

whose design allowed meeting the said standard without aftertreatment with a potential for further Euro standard compliance. These are DC9 engines of the capacity of $9.3 \mathrm{dm}^{3}$ (increased in comparison to the previous engine version by $0.4 \mathrm{dm}^{3}$ ) and DC13 of the capacity of $12.7 \mathrm{dm}^{3}$, commonly referred to as the 9 and 13-liter engines. The new engines were fitted with exhaust gas recirculation, variable geometry turbochargers and common rail fuel injection. The engines are manufactured in several power output variants: the 9-liter engine comes with $169 \mathrm{~kW}$ (230 BHP), $206 \mathrm{~kW}$ (280 BHP) and $235 \mathrm{~kW}$ (320 BHP). The13-liter engine has the power ranging from $265 \mathrm{~kW}$ (360 BHP), $294 \mathrm{~kW}$ (400 BHP), $324 \mathrm{~kW}$ (440 BHP) to $353 \mathrm{~kW}(480 \mathrm{BHP})$. In practice, this gives the clients a very flexible and convenient choice of the engine power output depending on the vehicle application. The new engines are distinguished by their traditional modular design (Fig. 10 and 11).

The 5-cylinder 9-liter engine has two balance shafts located in a modified oil sump and a maintenance free DPF filter in order to meet the EEV requirements for engines of power output of $169 \mathrm{~kW}$ (230 BHP) and $206 \mathrm{~kW}$ (280 BHP). In the 13-liter engine, in order to boost the block rigidity and reduce the noise level an additional ribbed element has been fitted in the block. For the production of the engine blocks Scania did not use the compacted graphite iron technology even though these blocks operate under heavy loads caused by extremely high combustion pressure reaching 200 bar (Fig. 12 and 13). wzrost temperatury sprężanego paliwa, konstrukcja układu zapewnia podgrzewanie paliwa w zbiornikach (rys. 8).

Układ HPI stosowany jest od 2001 r. do dzisiaj w silnikach spełniających standardy Euro 3, Euro 4 i Euro 5. Przykładem popularnego silnika wyposażonego w ten układ jest spełniającego normy Euro 4 silnik DT12 12 z układem turbocompound oraz recyrkulacją spalin, natomiast silnik DT12 15 HPI o mocy 309 kW (420 KM) wyposażony w układ SCR (selective catalitic reduction) spełnia standardy Euro 5 (rys. 9).

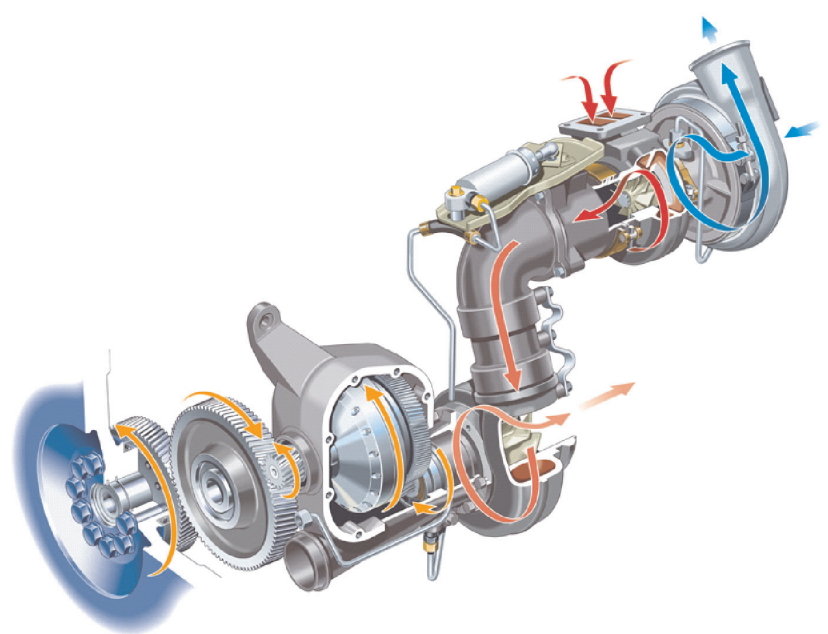

Fig. 9. The schematics of turbocompound by Scania DT12 $346 \mathrm{~kW}(470$ BHP)

Rys. 9. Układ turbocompound silnika Scania DT12 346 kW (470 KM)

\section{Nowa rodzina silników Scania}

W roku 2007, dwa lata przed wprowadzeniem standardów Euro 5, Scania zaprezentowała nową rodzinę silników, których konstrukcja pozwala na spełnienie ich wymagań bez oczyszczania spalin oraz umożliwia ich dalszy rozwój odnośnie do spełnienia wyższych standardów. Są to silniki DC9 o pojemności skokowej 9,3 $\mathrm{dm}^{3}$ (zwiększonej w stosunku do poprzedniej wersji silnika o $\left.0,4 \mathrm{dm}^{3}\right)$ i DC13 o pojemności skokowej $12,7 \mathrm{dm}^{3}$, potocznie nazwane silnikami dziewięcio- i trzynastolitrowymi. Nowe silniki wyposażone zostały w układy recyrkulacji spalin, turbosprężarki o zmiennym położeniu kierownic oraz układy wtrysku paliwa common rail. Silniki produkowane są w kilku wariantach mocy: silnik 9-litrowy dostępny jest w wersji 169 kW (230 KM), 206 kW (280 KM) i 235 kW (320 KM). Silnik 13-litrowy może osiągać moc 265 kW (360 KM), 294 kW (400 KM), 324 kW (440 KM) lub 353 kW (480 KM). Daje to w praktyce bardzo elastyczną możliwość doboru mocy silnika do zapotrzebowania związanego z przeznaczeniem i charakterem pracy pojazdu ciężarowego. Nowe silniki wyróżnia tradycyjna dla firmy Scania konstrukcja modułowa (rys. 10 i 11).

Pięciocylindrowy silnik dziewięciolitrowy został wyposażony w dwa wałki wyrównoważające w zmodyfikowanej misce olejowej oraz, w celu spełnienia wymagań EEV, bezobsługowy filtr cząstek stałych dla silników o mocy $169 \mathrm{~kW}$ (230 KM) i 206 kW (280 KM). W silniku trzynastolitrowym 


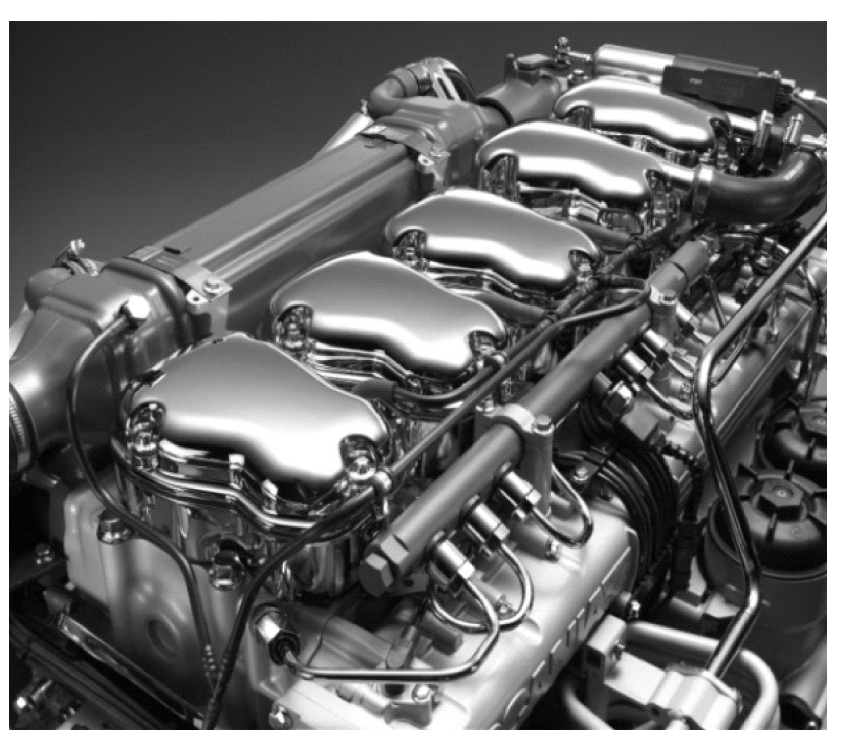

Fig. 10. DC9 XPI 169/206/235 kW (230/280/320 BHP) (cylinder bore $130 \mathrm{~mm}$, piston stroke $140 \mathrm{~mm}$, compression ratio 17)

Rys. 10. Silnik DC9 XPI 169/206/235 kW (230/280/320 KM) (średnica cylindra $130 \mathrm{~mm}$, skok tłoka $140 \mathrm{~mm}$, stopień sprężania 17)

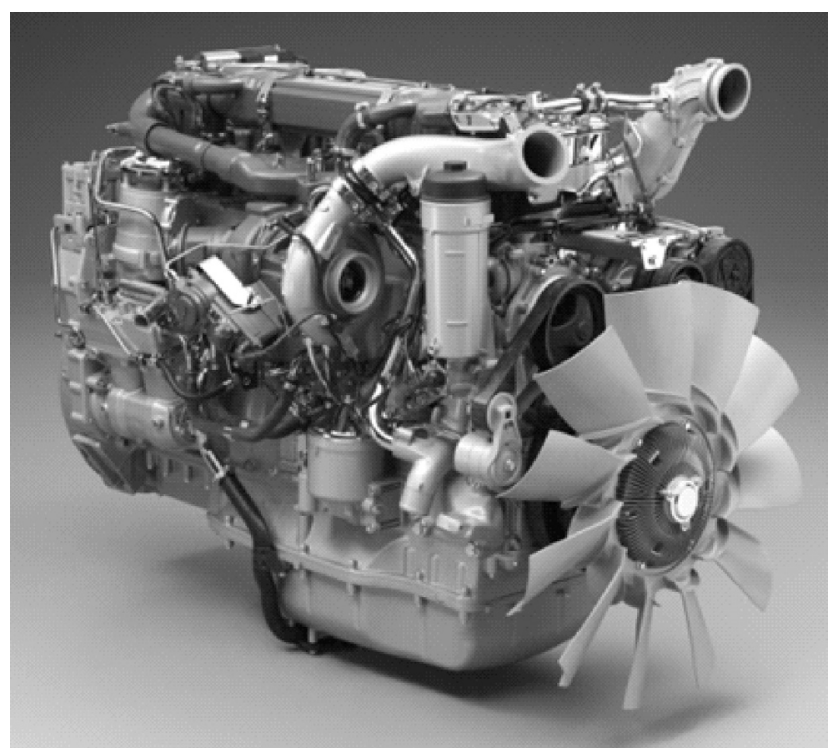

Fig. 12. DC13 XPI 265/294/324/353 kW (360/400/440/480 BHP) (cylinder bore $130 \mathrm{~mm}$, piston stroke $160 \mathrm{~mm}$, compression ratio 17.3)

Rys. 12. Silnik DC13 XPI 265/294/324/353 kW (360/400/440/480 KM) (średnica cylindra $130 \mathrm{~mm}$, skok tłoka $160 \mathrm{~mm}$, stopień sprężania 17,3)

\subsection{Reducing the exhaust emissions}

A reduction in the $\mathrm{NO}_{\mathrm{x}}$ emission in modern engines is ensured by the exhaust recirculation fitted with a two stage cooling system. EGR has been applied in Euro 4 compliant engines, but the amount of the recirculated exhaust gases in new engines is much higher (Fig. 14, tab. 1).

In order to reduce the emission of PM in their new engines Scania uses:

- high air excess coefficient,

- high supercharge pressure,

- high fuel injection pressure (maximum operating pressure 2400 bar),

- multiphase fuel injection (post injection in particular).

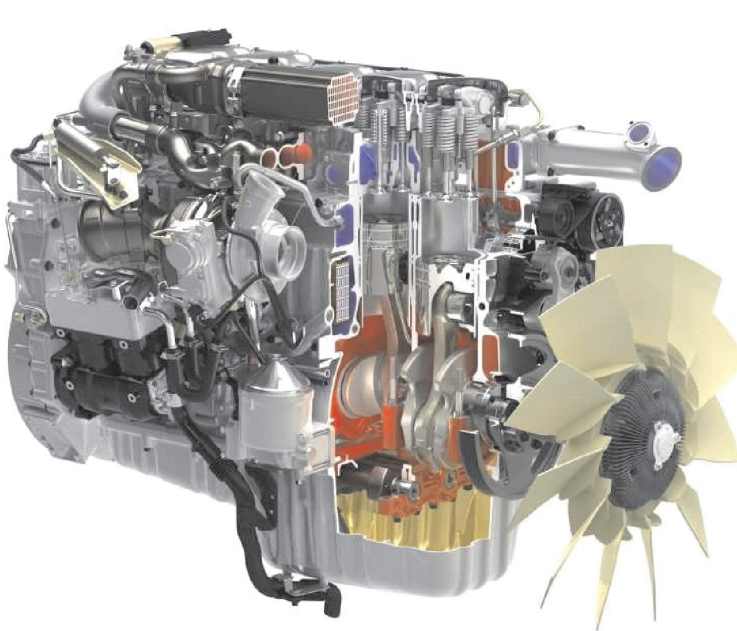

Fig. 11. DC9 XPI cross section Rys. 11. Przekrój silnika DC9 XPI

w celu zwiększenia sztywności bloku i ograniczenia hałasu zastosowano dodatkowy, użebrowany element kadłuba silnika. Scania do produkcji kadłubów nie zastosowała technologii ,compacted graphite iron”, pomimo że są one mocno obciążone m.in. bardzo wysokim ciśnieniem w komorze spalania dochodzącym do 200 bar (rys. 12 i rys. 13).

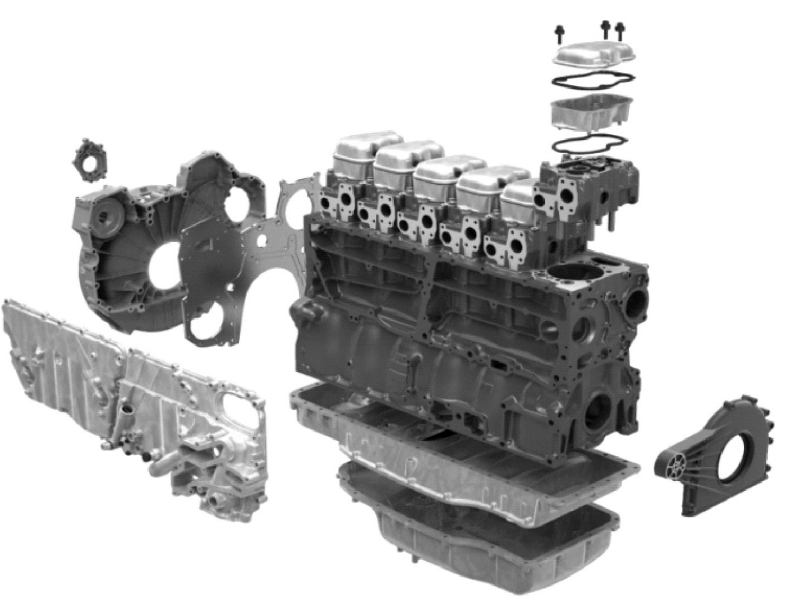

Fig. 13. DC13 XPI engine block

Rys. 13. Kadtub silnika DC13 XPI

\subsection{Zmniejszenie emisji składników toksycznych spalin}

Zmniejszenie emisji tlenków azotu w nowych silnikach zapewniają układy recyrkulacji spalin z dwustopniowym układem chłodzenia. Układ EGR zastosowano już w silnikach spełniających normy Euro 4, ale ilość spalin zawracana do cylindra w nowych silnikach jest znacznie większa (rys. 14, tab. 1). Aby zmniejszyć emisję cząstek stałych w nowych silnikach Scania stosuje:

- duży współczynnik nadmiaru powietrza,

- duże ciśnienie doładowania,

- duże ciśnienie wtrysku paliwa (maksymalne ciśnienie robocze 2400 bar),

- wielofazowy wtrysk paliwa (w szczególności „powtrysk"). 


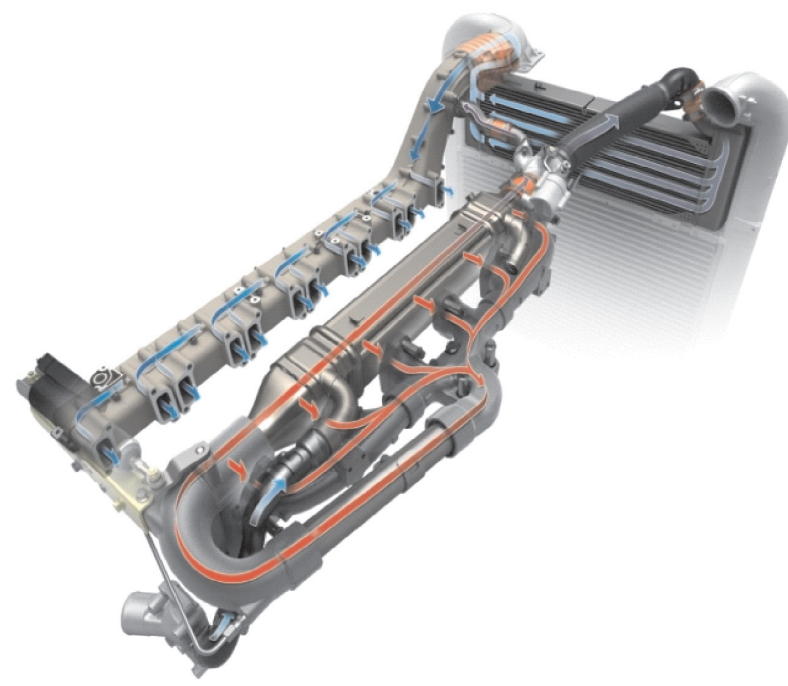

Fig. 14. Exhaust gas recirculation system in DC13 XPI Rys. 14. Uktad recyrkulacji spalin silnika DC13 XPI

\subsection{Engine turbocharging}

The engines are fitted with turbochargers by Cummins Turbo Technologies (former Holset). They have an adjustable exhaust gas flow through the turbine, thus a variable amount and pressure of the charging air. The adjustment is made through a sliding ring that controls the gas flow. The ring is adjusted by electric actuators that are much faster than the pneumatic ones. The operation of the system is particularly important in the range of low engine speeds in order to obtain a high torque. The compressed air is also used to an early gearshift in the automatic gearshift system Opticruise (Fig. 15).
Table 1. The comparison of the parameters of the EGR systems used in 12-liter Euro 4 engines and 13-liter Euro 5 engines

Tabela 1. Porównanie parametrów układów EGR stosowanych w 12-litrowych silnikach spetniajacych normy Euro 4 i 13-litrowych silnikach Euro 5

\begin{tabular}{|l|c|c|}
\hline Emission standard/normy emisji & Euro 4 & Euro 5 \\
\hline EGR burden/udział EGR & $15-20 \%$ & $25-30 \%$ \\
\hline $\begin{array}{l}\text { Amount of heat transferred in the exhaust } \\
\text { cooling system/ilość odprowadzanego ciepła } \\
\text { w uktadzie chłodzenia spalin }\end{array}$ & $35 \mathrm{~kW}$ & $70 \mathrm{~kW}$ \\
\hline $\begin{array}{l}\text { Exhaust temperature after cooling/temperatura } \\
\text { spalin po schtodzeniu }\end{array}$ & $150^{\circ} \mathrm{C}$ & $50^{\circ} \mathrm{C}$ \\
\hline
\end{tabular}

\subsection{Turbodoładowanie silników}

Silniki doładowane są turbosprężarkami firmy Cummins Turbo Technologies (dawniej Holset). Zapewniają one regulację przepływu spalin przez turbinę, a tym samym zmienny wydatek i zmienne ciśnienie powietrza doładowującego silnik. Regulację umożliwia przesuwny pierścień regulujący przepływ spalin. Do ustawienia położenia pierścienia wykorzystany jest układ elektryczny, znacznie szybszy i bardziej precyzyjny od stosowanych układów pneumatycznych. Bardzo ważna jest praca układu w zakresie małej prędkości obrotowej silnika umożliwiająca uzyskanie dużego momentu obrotowego silnika. Sprężone w układzie powietrze wykorzystywane jest również do wcześniejszej zmiany biegów w układzie automatycznej zmiany biegów Opitcruise (rys. 15).

\subsection{Układ zasilania silników}

Podobnie jak układ wysokociśnieniowego wtrysku paliwa HPI, również układ XPI (extra-high pressure injection) jest wynikiem współpracy firm Scania i Cummins. To bardzo elastyczny i precyzyjny układ dający ogromne możliwości regulacji dawkowania paliwa, które może być wtryskiwane wielokrotnie na jeden cykl pracy. Maksymalne ciśnienie wtrysku osiąga wartość 2400 bar, ale zależy ono od warunków pracy silnika i nie jest utrzymywane stale na tak wysokim poziomie, gdyż wymaga to dostarczenia do układu wtryskowego dużej energii. Średnia wartość ciśnienia wtrysku wynosi 1800 bar, a wartość minimalna 850 bar. Układ ma bardzo krótki czas reakcji. Zmiana prędkości obrotowej silnika od 1200 1/min do 1900 1/min i osiągniecie mocy maksymalnej zajmuje ok. 250 milisekund (5 obrotów silnika) - rys. 16 .

\subsection{Elektroniczny układ sterujący}

Elektroniczny układ sterujący silnikiem może współpracować $\mathrm{z}$ 20 jednostkami sterującymi w pojeździe oraz wysyłać i odbierać 140 sygnałów. 


\subsection{Fuel feed system}

Similarly to the high-pressure fuel injection (HPI), the XPI (extra-high pressure injection) system is a result of a collaboration of Scania and Cummins. It is a very flexible and accurate system having a great potential in fuel dose adjustment, allowing multiple injections in a single engine cycle. The maximum injection pressure reaches 2400 bar but it depends on the engine operating conditions and is not continuously maintained on the same level as it requires a lot of energy to ensure such a pressure. An average value of the fuel injection amounts to 1800 bar, and the minimum value reaches 850 bar. The system has a very short reaction time. A change in the engine speed from $1200 \mathrm{rpm}$ to $1900 \mathrm{rpm}$ and reaching the maximum power takes approximately 250 milliseconds (5 engine revolutions) - Fig. 16.

\subsection{Electronic control system}

The electronic engine control system can work with 20 control units in the vehicle and send and receive 140 signals.

Some functions of the ECU that control:

- fuel injection parameters (XPI),

- charging pressure and mixture composition (VGT),

- exhaust gas recirculation parameters (EGR),

- engine temperature (fan control),

- engine brake,

- on-board diagnostics (OBD).

With the new diagnostic tool - Scania Communicator - a remote diagnostics from the ECD is possible through a fleet management system (Scania Fleet Management).

\subsection{The Euro 5 engine performance}

Owing to the modern technology applied in the Scania engines they obtain a high torque values and a high overall
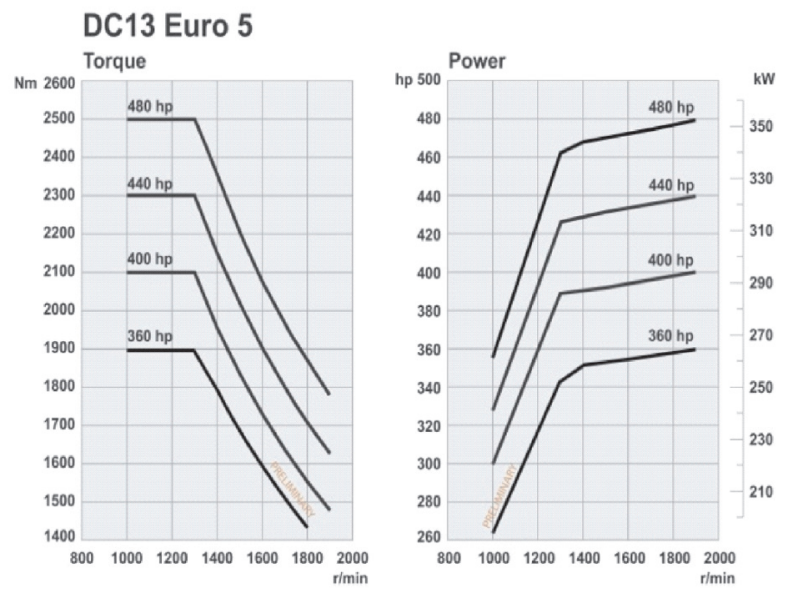

Fig. 17. External speed characteristics of the DC13 Euro 5 engines Rys. 17. Charakterystyki prędkościowe zewnętrzne silników DC13 Euro 5

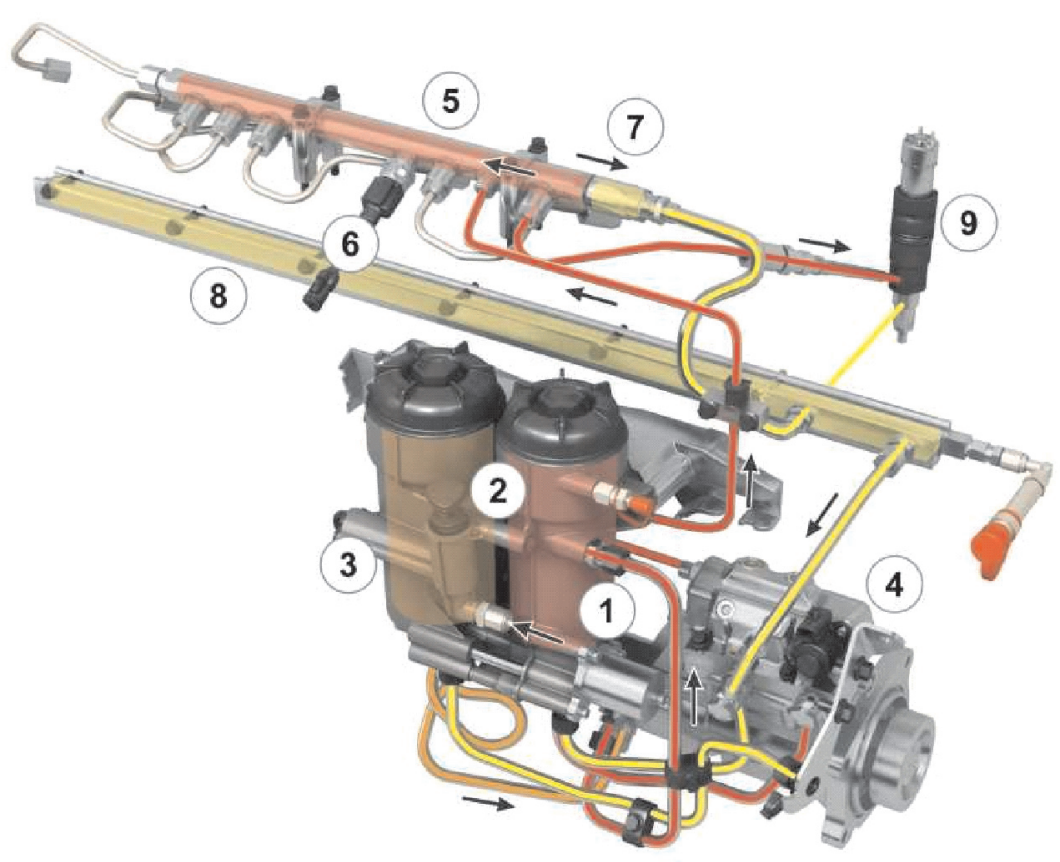

Fig. 16. Scania fuel injection system XPI: 1 - feeding pump, 2 - fuel filters with water separators, 3 - dosage valve, 4 - high pressure pump, 5 - fuel rail, 6 - fuel pressure, 7 - mechanical overflow valve, 8 - return fuel rail, 9 - electronically controlled injector

Rys. 16. Układ wtryskowy Scania XPI: 1 - pompa zasilajaca, 2 - filtry paliwa z separatorem wody, 3 -zawór dozujący, 4-pompa wysokiego ciśnienia, 5-magistrala paliwowa, 6-czujnik ciśnienia, 7 -mechaniczny zawór przelewowy, 8 -magistrala powrotna, 9 -elektronicznie sterowany wtryskiwacz

Ważniejsze funkcje układu ECU to kontrola i sterowanie: - parametrami wtrysku paliwa (XPI), - ciśnienia doładowania i składu mieszanki (VGT), - parametrami recyrkulowanych spalin (EGR),

- temperatury silnika (sterowanie pracą wentylatora),

- hamulcem silnikowym.

oraz diagnostyka pokładowa (OBD). Za pomocą nowego przyrządu diagnostycznego Scania Communicator możliwy jest zdalny odczyt danych z ECD za pośrednictwem systemu zarządzania flotą Scania Fleet Management.

\subsection{Osiągi silników Euro 5}

Dzięki zastosowaniu zaawansowanych technologii silniki Scania osiągają dużą wartość momentu obrotowego oraz cechuje je bardzo duża sprawność ogólna dochodząca do 44\%. Do oceny ich właściwości użytkowych służy m.in. prosty parametr, tj. stosunek maksymalnego momentu obrotowego do mocy maksymalnej. Inżynierowie firmy Scania starają się utrzymać ten stosunek na poziomie nieco wyższym niż 5, czasem żartując, że firma, sprzedając pojazd wyposażony w odpowiedni silnik, sprzedaje jego moc, ale oceniana jest według tego, jaki moment obrotowy rozwija silnik (rys. 17 i 18).

Oprócz silników rzędowych Scania oferuje również silniki V8. W wersji spełniającej normy Euro 5 są one wyposażone w układ SCR (selective catalitic reduction) i osiągają moc 368 kW (500 KM), 412 kW (560 KM) lub 456 kW (620 KM) (rys. 19). 
efficiency reaching 44\%. To evaluate their usable properties we can use one simple parameter i.e. the ratio of the maximum torque to the maximum power. The Scania engineers try to keep that ratio at the level just above 5 sometimes joking that the company, by selling a vehicle fitted with an appropriate engine, actually sells its power output, but is evaluated by its torque (Fig. 17 and 18).

Beside in-line engines Scania manufactures V8 engines. In the version complying with the Euro 5 emission standard they are fitted with the SCR system (selective catalytic reduction) and have the power output of $368 \mathrm{~kW}$ (500 BHP), 412 $\mathrm{kW}(560 \mathrm{BHP})$ or $456 \mathrm{~kW}$ (620 BHP) (Fig. 19).

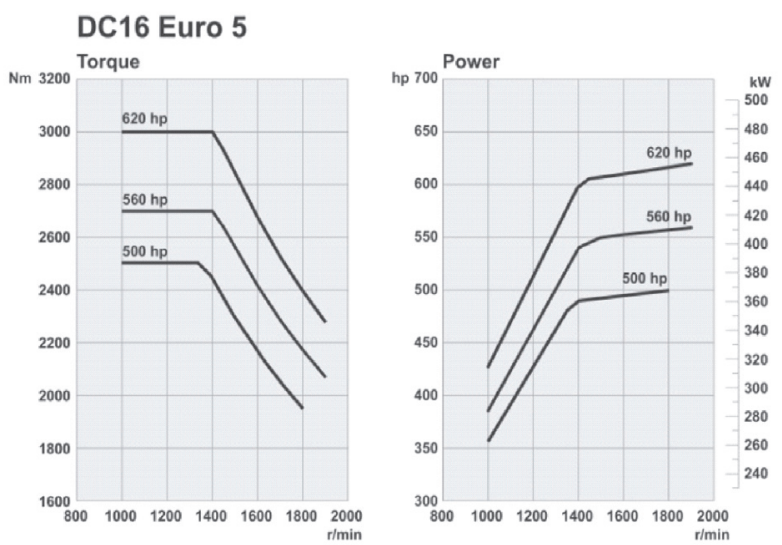

Fig. 19. External speed characteristics of the DC16 Euro 5 engines Rys. 19. Charakterystyki prędkościowe zewnętrzne silników DC16 Euro 5

\section{An ethanol engine}

Since 1989 Scania has been developing ethanol technology (using ethanol as the primary fuel for their diesel engines). Currently, they boast an engine whose maximum overall efficiency that amounts to approximately $43 \%$, is comparable to the efficiency of a traditional diesel-fueled engine and much higher than spark ignition engines. For the ethanol engine whose compression ratio was increased to 28 , ethanol is used with a $5 \%$ additive that facilitates ethanol self-ignition and protects the engine against corrosion. The ethanol-fueled engine is fitted with EGR. The displacement of this engine is $8.9 \mathrm{dm}^{3}$, power output $199 \mathrm{~kW}(270$ BHP) at $1900 \mathrm{rpm}$; the engine has a torque of $1200 \mathrm{~N} \cdot \mathrm{m}$ at 1100-1400 rpm.

The engine is used in buses and the demand for this engine type is constantly growing due to very low exhaust emissions falling into the category of Euro 5 as well as EEV (Fig. 20).

\section{Trends in the further development}

At the end of 2008 the European Parliament adopted a Euro 6 draft rule that provides for harmonized technical regulations for heavy-duty vehicles of payload exceeding $2610 \mathrm{~kg}$. More stringent $\mathrm{CO}, \mathrm{NO}_{\mathrm{x}}, \mathrm{HC}$ and PM limits are to become binding from 31 December 2013. The admissible $\mathrm{NO}_{\mathrm{x}}$ emission limit was set at the level of 400 $\mathrm{mg} / \mathrm{kW} \cdot \mathrm{h}$, hence $80 \%$ lower than the Euro 5 emission stand-

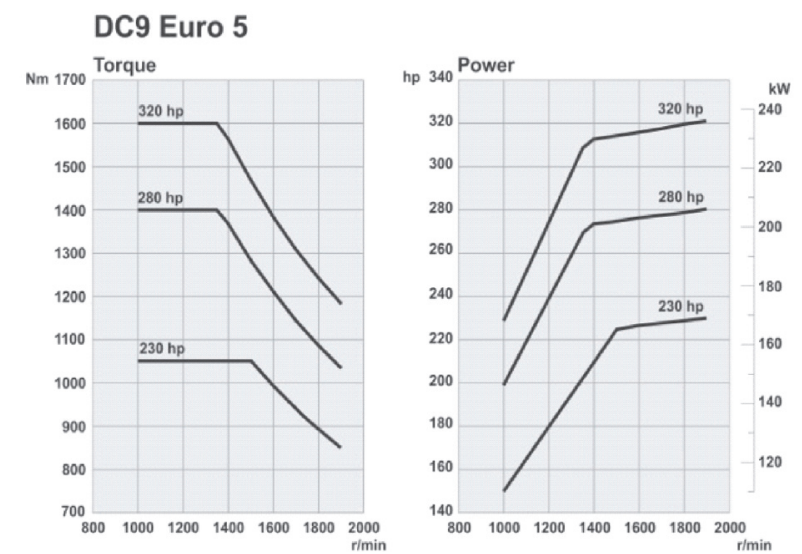

Fig. 18. External speed characteristics of the DC9 Euro 5 engines Rys. 18. Charakterystyki prędkościowe zewnętrzne silników DC9 Euro 5

\section{Silnik zasilany etanolem}

Od roku 1989 Scania intensywnie rozwija technologię wykorzystującą etanol jako paliwo do silników z zapłonem samoczynnym. Obecnie może pochwalić się silnikiem, którego maksymalna sprawność ogólna, wynosząca ok. $43 \%$, jest porównywalna do sprawności silnika z zapłonem samoczynnym zasilanego konwencjonalnie olejem napędowym i dużo większa niż osiągana przez silniki z zapłonem iskrowym. Do zasilania silnika, którego stopień sprężania zwiększono do 28 używany jest etanol z 5-procentowym dodatkiem ułatwiającym jego samozapłon i zabezpieczający silnik przed korozją. Silnik zasilany etanolem wyposażony jest w układ EGR. Pojemność skokowa to $8,9 \mathrm{dm}^{3}$, moc 199 kW (270 KM) przy prędkości obrotowej 1900 1/min; silnik rozwija moment obrotowy $1200 \mathrm{~N} \cdot \mathrm{m}$ przy prędkości obrotowej 1100-1400 1/min.

Silnik stosowany jest w autobusach, a zapotrzebowanie na niego wzrasta ze względu na bardzo niski poziom emisji składników toksycznych spalin, mieszczący się w wymaganiach zarówno norm Euro 5, jak również EEV (rys. 20).

\section{Kierunki rozwoju}

Pod koniec 2008 roku Parlament Europejski przyjął projekt rozporządzenia w sprawie normy Euro 6, które przewiduje wprowadzenie zharmonizowanych przepisów technicznych dla pojazdów ciężarowych o ładowności ponad 2610 kg. Ostrzejsze normy emisji tlenku węgla, tlenków azotu, węglowodorów i cząstek stałych mają obowiązywać od 31 grudnia 2013 r. Dopuszczalna wartość emisji tlenków azotu została określona na poziomie $400 \mathrm{mg} / \mathrm{kW} \cdot \mathrm{h}$, a więc o 80\% niższym niż w normie Euro 5. Limity emisji cząstek stałych zostaną zmniejszone o $66 \% \mathrm{w}$ porównaniu do Euro $5 \mathrm{i}$ wyniosą $10 \mathrm{mg} / \mathrm{kW} \cdot \mathrm{h}$.

Równolegle do proponowanego rozporządzenia opracowane zostaną przepisy określające specyfikacje techniczne. Komisja Europejska powinna je przyjąć przed 1 kwietnia 2010 r., aby dać czas producentom na dokonanie niezbędnych zmian technologicznych. Są to nowe wyzwania dla rozwoju silnika. Scania przygotowuje rozwiązania mające 
ard. The emission limits for PM shall be tightened by $66 \%$ as opposed to the Euro 5 standard and shall reach the level of 10 $\mathrm{mg} / \mathrm{kW} \cdot \mathrm{h}$.

Parallel to the proposed rule, legislation determining the technical specifications shall be developed. The European Commission should pass them before April 1, 2010 to provide ample time for the manufacturers to implement the necessary technological changes. These are new challenges for the engine development. Scania has been preparing solutions that will soon meet the new requirements. The works on the HCCI (homogeneous compression ignition engine) are under way. This idea has already been applied in the Scania engines with $30 \%$ of the maximum engine load. The combustion of homogenous lean mixtures is being tested in diesel engines fueled with a variety of fuels, including alternative fuels. The organization of the combustion process is possible thanks to a constant perfecting of the EGR, XPI or VGT systems already applied in the new engine family not to mention the VVT (variable valve timing). Scania also works on hybrid technology. The significance of alternative fuels grows. That is why the Scania engineers say: give us a fuel and we will find a way to burn it in an efficient and clean way. The emission of

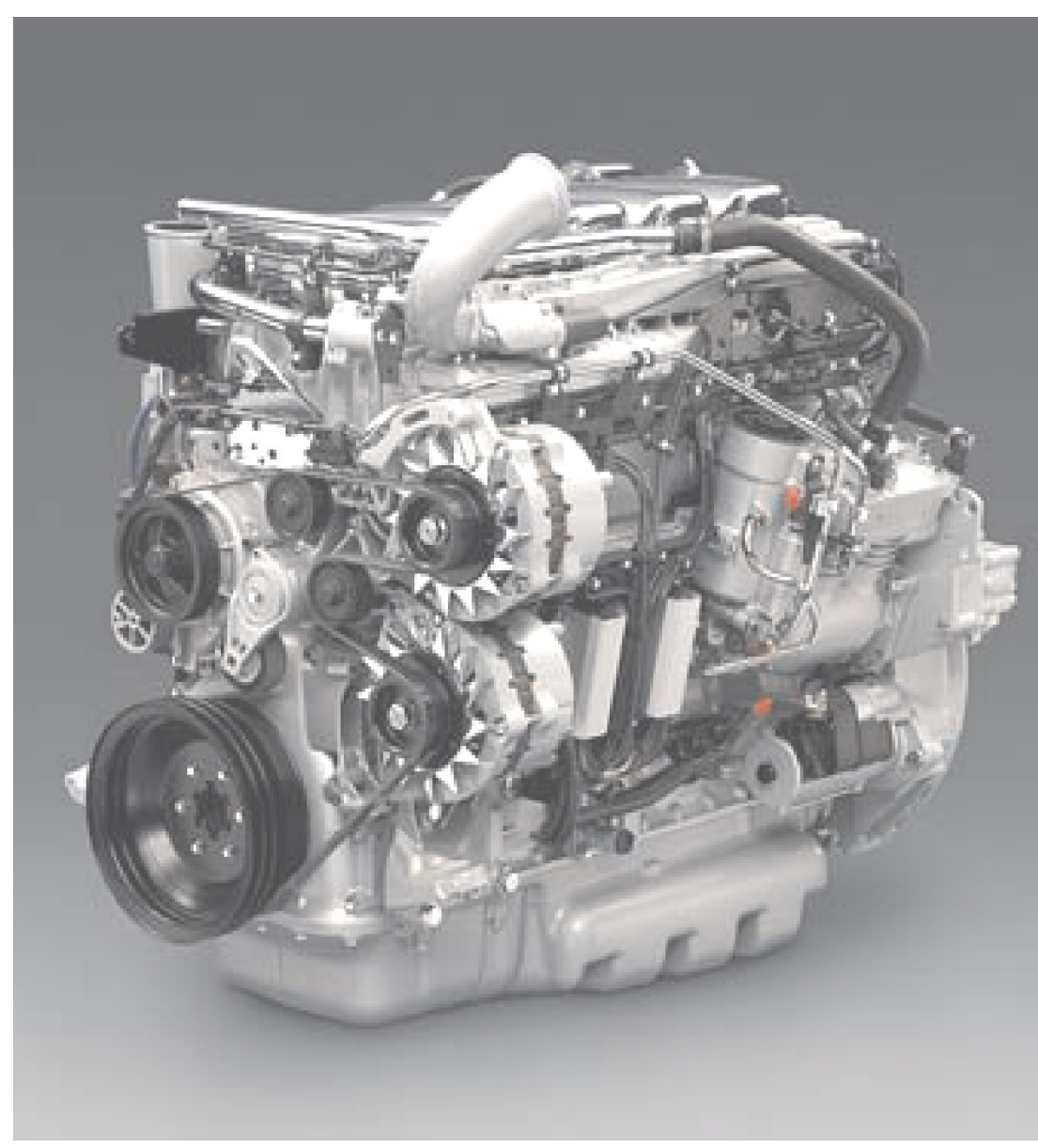

Fig. 20. Scania engine fueled with ethanol (Euro 5, EEV)

Rys. 20. Silnik Scania zasilany etanolem (Euro 5, EEV)

carbon monoxide shall be reduced which is directly related to the reduction of the fuel consumption - definitely an asset of the Scania engines. One thing stays clear: a self-ignition engine has a long and bright future and the pace of the works on its development, including the reduction of the emissions (up to zero emission) is getting faster.

All images and figures presented in this paper are courtesy of: http://imagebank.scania.com and are the property of Scania.

Paper reviewed/Artykut recenzowany

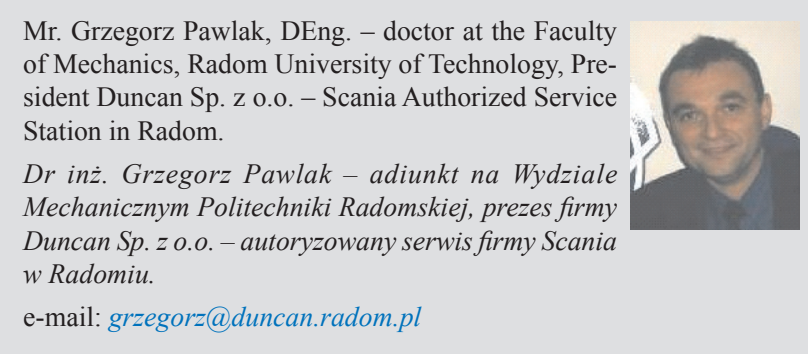

wkrótce spełnić nowe wymagania. Trwają prace nad silnikiem HCCI (homogeneous compression ignition engine). Idea ta jest już realizowana w silnikach Scania obciążonych do $30 \%$ obciążenia maksymalnego. Badane jest spalanie jednorodnych mieszanek ubogich w silniku z zapłonem samoczynnym zasilanych różnymi paliwami, w tym paliwami alternatywnymi. Organizacja procesu spalania możliwa jest dzięki doskonaleniu układów EGR, XPI, VGT już stosowanych w nowej rodzinie silników oraz dodatkowo układu VVT (variable valve timing). Rozwijane są technologie napędu hybrydowego. Wzrasta znaczenie paliw alternatywnych, dlatego popularne wśród inżynierów firmy Scania, zajmujących się rozwojem silników, stwierdzenie: ,dajcie nam paliwo, a my znajdziemy sposób jak je efektywnie i czysto spalić w silniku" jest coraz bardziej aktualne. Ograniczeniu ulegać będzie również emisja dwutlenku węgla, a to wiąże się ze zmniejszeniem zużycia paliwa, co jest bardzo mocną stroną silników Scania. Jedno jest pewne: silnik z zapłonem samoczynnym ma przed sobą długą i dobrą przyszłość, a prace mające na celu jego rozwój, w tym ograniczenie emisji do wartości bliskich zeru, nabierają coraz większego tempa.

Wszystkie fotografie i rysunki zamieszczone $w$ artykule pochodza ze strony: http://imagebank.scania.com i sq własnościa firmy Scania. 